19 Revue d'histoire du XIXe siècle

Société d'histoire de la révolution de 1848 et des

révolutions du XIXe siècle

8 | 1992

Jeunesses au XIXe siècle

\title{
Jeunesses rurales dans la France du XIXe siècle
}

Jean-Claude Farcy

URL: http://journals.openedition.org/rh19/59

DOI: $10.4000 /$ rh 19.59

ISSN: $1777-5329$

Publisher

La Société de 1848

Printed version

Date of publication: 1 June 1992

ISSN: 1265-1354

Electronic reference

Jean-Claude Farcy, " Jeunesses rurales dans la France du XIXe siècle », Revue d'histoire du XIXe siècle [Online], 8 | 1992, Online since 09 September 2008, connection on 20 April 2019. URL : http:// journals.openedition.org/rh19/59; DOI : 10.4000/rh19.59

This text was automatically generated on 20 April 2019

Tous droits réservés 


\section{Jeunesses rurales dans la France du XIXe siècle}

Jean-Claude Farcy

\section{ABSTRACTS}

No abstract available by now

Pas de résumé disponible actuellement

INDEX

Mots-clés: Jeunesse, Histoire rurale 